\title{
GROWTH INHIBITORS IN TURFGRASS ${ }^{1}$
}

\author{
Inibidores de Crescimento em Gramados
}

MARCH, S.R. ${ }^{2}$, MARTINS, D. ${ }^{3}$, and McELROY, J.S. ${ }^{4}$

\begin{abstract}
Well-maintained lawns are comfortable and safe places for leisure activities and sports practice, and they also bring environmental benefits; for example, they reduce soil exposure to erosion and releases atmospheric $\mathrm{CO}_{2}$, thus reducing the greenhouse effect. However, regardless of the purpose of use or the choice of the plant species to form the lawn, the highest costs involve cutting that is needed to keep the turfgrass at its appropriate height. Successive lawn cutting operations are necessary basically because of the vegetative and reproductive growth of turfgrass which, in Brazil, occurs mainly from October to March. Expenditures with successive mechanical cuttings have fostered the search of alternative procedures to keep lawn plants at appropriate height, such as the use of plant growth inhibitors, an increasingly interesting procedure. Since the use of this technology in Brazil is still at its early stage, the aim of this literature review is to examine aspects associated with lawn management by using growth inhibitors. Another alternative is to increase the knowledge of the classification and rational application of the different compounds currently available in the market.
\end{abstract}

Keywords: growth regulator, lawn, bio-stimulant, injury, selectivity, herbicide.

RESUMO - Um gramado bem mantido proporciona local confortável e seguro para diversão e prática de esportes, reduz a exposição do solo à erosão, libera oxigênio e captura $\mathrm{CO}_{2}$ atmosférico, atenuando o efeito estufa. Contudo, independentemente da modalidade de uso ou da escolha da espécie, o principal fator do custo de manutenção dos gramados é o corte para manter a altura adequada. As sucessivas operações de corte estão basicamente relacionadas ao crescimento vegetativo e florescimento da grama, sobretudo nos meses de outubro a março. O dispêndio com os cortes sucessivos leva à procura de alternativas para o manejo mecânico, tendo como possibilidade o uso de inibidores de crescimento vegetal. Como o uso dessa tecnologia em gramados no Brasil ainda é muito incipiente, pretende-se neste texto de revisão abordar os aspectos relativos ao manejo de gramados pelo uso de substâncias inibidoras do desenvolvimento vegetal, bem como atualizar os conhecimentos quanto à classificação e aplicação racional dos diferentes compostos atualmente disponiveis.

Palavras-chave: reguladores de crescimento, gramado, bioestimulante, injúria, seletividade, herbicida.

\section{INTRODUCTION}

Grazing by sheep and other domestic animals was the first lawn growth control method reported to be applied by American farmers. This procedure lasted until 1830, when it started to be replaced by the revolutionary grass cutter invented by Edwin Buding. Since then, keeping lawns at the appropriate height by using mechanical cutters became a routine practice in the USA (Watschke \& DiPaola, 1995).

The mechanical cutter had the advantage of being faster than animal grazing in addition to resulting in lawns with more uniform height. On the other hand, the successive cutting operations, mainly during the spring

Recebido para publicação em 2.2.2013 e aprovado em 2.6.2013.

2 Associate Professor, ICET/UFMT, Barra do Garça-MT, <sidneimarchi.ufmt@gmail.com>; ${ }^{3}$ Professor Livre Docente, Dept. of Vegetal Production, FCA/UNESP, Botucatu-SP, <dmartins@fca.unesp.br>; ${ }^{4}$ Ph.D., Associate Professor of Weed Science, Department of Agronomy and Soil, Auburn University, Auburn/AL, E.U.A., <jsm0010@auburn.edu>. 
and summer months, became the most important cost factor for lawn maintenance. In addition to that, the huge amounts of clippings resulting from the cuttings and the trouble of disposing of the clippings further exacerbated the cost of mowing. In spite of such disadvantages, the mechanical cutting of lawns was used for more than 100 years after its invention when the first research results started to be published on the use of chemical products to inhibit plant growth.

Researchers all over the world have been interested in controlling plant growth by means of exogenous chemical substances since the mid-1940s, when maleic hydrazide was used for the first time as the first commercial product used for that purpose. Later on, with the launching of chlorine choline chloride (CCC), a product which was widely used during the 1960s and 1970s (Cooke, 1987), controlling plant growth by means of chemical substances became even more usual.

Coincidentally, the use of growth regulators for the specific control of lawn plants growth also started soon after World War II, at the end of the 1940s. The objective at that time was to increase the intervals between cuttings. The products during that time were more like growth retarders than growth regulators. And herein is a key point. A growth retarder is a chemical that reduces growth by indiscriminate injury to the plant; thus, at high rates growth retarders can become herbicides. Growth regulators are chemicals that specifically target and inhibit biochemical pathways that cause vertical growth.

A large number of products were tested after World War II but most of them failed to suppress plant growth. Among them were cell division inhibitors such as $N$-Dimethylamino succinamic acid, phosphonium, ethephon, gibberelic acid, and kinetin. $N$-Dimethylamino succinamic acid, CCC, and phosphonium were not only inefficient but also caused severe damage to the lawns (Stier, 2006).

Ethephon was the first registered product that was less phytotoxic among those commercially available at that time (Freeborg \& Daniel, 1981). Ethephon was largely used up to the beginning of the 1990s, when its potential use in lawns was reevaluated.
Other products were also used with the same objective between the 1950s and the 1960 s, mainly some synthetic gibberellins, maleic hydrazide, and chlorflurenol. Among those three, maleic hydrazide was the one receiving more attention because it was also used to curb the growth of grasses alongside roads and sidewalks (Stier, 2006).

During the 1970s and the 1980s, new compounds that promised to be less phytotoxic and more efficient were launched. Mefluidide was one of the most important compounds because it inhibited plant growth for long periods, reduced leaf expansion, and was less toxic to plant roots (Watschke et al., 1977). In addition to that, mefluidide received special attention because it was the first product which, at low doses, could inhibit not only cell division but also cell elongation (Stier, 2006).

The most important evolution in plant growth regulators took place in the 1990s, with the release of modern compounds capable of reducing vertical growth of lawn plants without affecting their lateral or root growth. Among those products, paclobutrazol, flurprimidol, trinexapac-ethyl, and, more recently, prohexadione-calcium were developed and released.

It should be noted that the main objective of growth regulators is to reduce plant height with no reduction in the form or function of the plant. Thus, the ideal lawn plant growth regulator should be a substance capable of reducing individual plant height with no reduction in plant density or capable of causing visible damage to the plants, such as phytotoxic necrotic spots, discoloration, or plant thinning while keeping a high quality in the treated area.

Applying plant growth regulators to lawns also aims to reduce emission and height of floral stems (Watschke \& DiPaola, 1995) in addition to reducing the number of cutting operations which take place during the summer and spring plant growth period, thus indirectly contributing to reduce costs with labor, fuel, and use of equipment. It is also necessary to consider that this technology helps to eliminate all the operations resulting from the cutting of the lawn plants such as chip raking, piling up, transporting, and disposal (Davis \& Curry, 1991). 
Plant growth regulators can also help to reduce the need of artificial irrigation and increase the efficiency of lawn-applied fungicides (Green et al., 1990; Burpee et al., 1996; Marcum \& Jiang, 1997; Jiang \& Fry, 1998; Burpee, 1998).

On the other hand, the use of plant growth regulators is directly associated with the level of technology adopted for the management and conservation of lawns. In the USA, for example, golf fields are maintained with a high level of quality. They demand a bigger number of plant cuttings than road sides or parks. Residential and industrial lawns, on the other hand, are maintained with low to medium levels of quality since their management is dependent on their owner's care. Therefore, the use of plant growth regulators is more frequently found in lawns managed with technology levels between medium and high, mainly those aimed at sports practice (Johnson, 1994). Low technology lawns are treated with plant growth regulators only when mechanical cutting of the plants is risky because of irregular topography or in river margins or alongside roads with heavy vehicle traffic (Dernoeden, 1984).

The use of plant growth regulators in Brazil is still considered incipient and it is observed to happen only in agricultural crops such as cotton, sugar cane, and some fruit species. Even less frequent is their use in lawns, regardless of whether or not they are used for sports, leisure, or residential purposes, or in roadside areas. This is evidenced by the very small number of papers on this subject published in Brazil and also by the lack of interest of producers of plant growth regulators in maintaining or financing research on the application of those products for lawn management purposes. The objective of this paper is, thus, to discuss issues associated with lawn management as regards the use of plant growth inhibiting substances, as well as to widen knowledge of the classification and rational use of the main products presently available in the market.

\section{CLASSIFICATION OF PLANT GROWTH REGULATORS}

Plant growth regulators are organic substances that, in small doses, are capable of affecting physiological and growth or developmental plant processes (Danneberger $\&$ Street, 1990; Arteca, 1995). These are substances which naturally occur in plants or result from artificial processes. When they occur naturally, they are called phytohormones or plant hormones, for example, auxins, gibberellins, cytokinins, ethylene, among others.

It should be noted that the word 'affect' is used for plant growth regulators without specification of how it interferes in plant growth and development. Various researchers use that word as if it meant only an inhibition or reduction of growth whereas the action exerted by a plant growth regulator may be one of growth stimulation as well. Thus, the most appropriate name for those compounds would be plant growth inhibitors. Analogically, the compounds capable of stimulating or promoting plant growth should be more appropriately referred to as biostimulants (Huang, 2007).

Plant growth-inhibiting compounds were initially classified as being of Type I or Type II. Type I growth inhibitors are absorbed by the leaf tissue and have a very quick paralyzing effect on cell division and differentiation at the meristematic regions in susceptible grass species. They also inhibit the growth of lateral branches and the emission of floral stems. Nevetheless, these compounds are also absorbed in the floral crown region or by roots in amounts that promote plant growth. Type II inhibitors suppress the development of grasses because they directly interfere in gibberellin biosynthesis thus reducing cell elongation and, consequently, growth (Watschke \& DiPaola, 1995; McCullough et al., 2004; Ervin $\&$ Zhang, 2007; Huang, 2007). However, the release of new products determined a further division of Type II into new groups based on their way of action (Figure 1). Therefore, the growth inhibitors are now divided into five classes (Watschke \& DiPaola, 1995).

Class A: substances capable of interfering with Phase 3 , that is, at the end of the gibberellin biosynthesis route by inhibiting $\mathrm{GA}_{20}$ hydroxilation to $\mathrm{GA}_{1}$. So, all the gibberellins preceding that phase are formed and may have some activity as growth regulators. Prehexadione-calcium and trinexapac-ethyl are examples of this class of inhibitors. There 


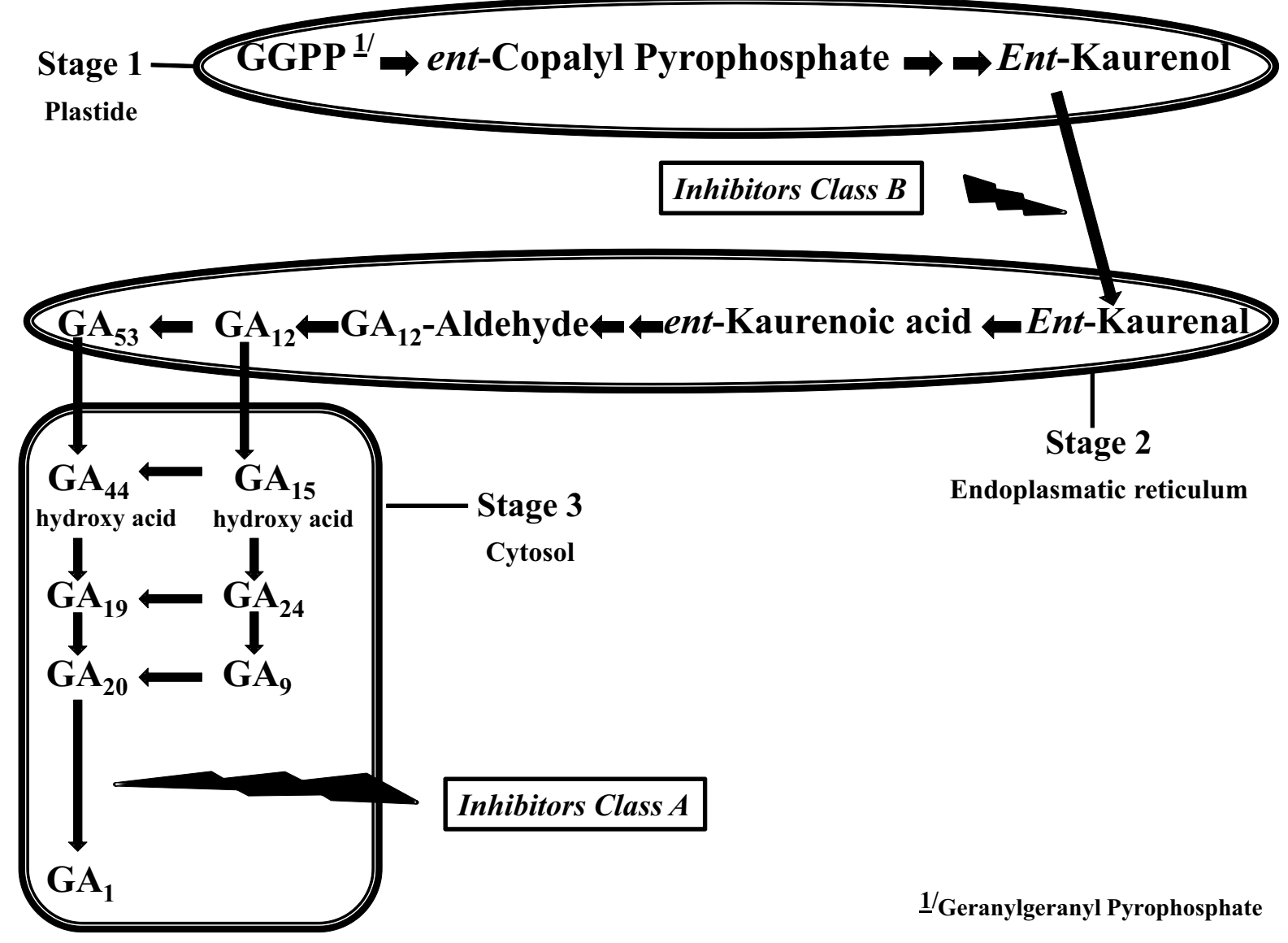

Figure 1 - Gibberellin biosynthesis: simplified route and locus of action of growth inhibitors. Class A and Class B.

is a powerful leaf growth inhibiting action but of a low activity level in reducing the number of floral stems.

Class B: substances which interfere in Phase 2 of gibberellin biosynthesis, that is, they block the action of the ent-kaurene oxidase enzyme which inhibits the conversion of ent-kaurene into ent-kaurenole and, consequently, prevents the formation of any type of gibberellin (McCullough et al., 2005a). Flurprimidol and Paclobutrazol are the most important examples of this class. They have a powerful action in the inhibition of leaf development, and low activity in the reduction of floral stem emission. Their use is limited by the degree of bronze appearance they produce in lawns.

Class C: these are mitosis-blocking substances that include all the compounds formerly known as Type I. They are very efficient in controlling leaf expansion and floral stem emission (Mittlesteadt, 2009) but they cause undesirable levels of staining in the plants.

Class D: some herbicides may also be used as plant growth regulators which, when applied in low doses or sublethal doses and at the right time, are capable of indirectly interfering in some physiological mechanisms in the plants although they do not cause visible damage. The most frequently used herbicides are glyphosate, imazaquin, imazapic, imazethapyr, metsulfuron-methyl (Davies \& Curry, 1991) and, more recently, bispyribac-sodium.

Class E: compounds under this classification can foster the production of ethylene, a plant hormone capable of inhibiting branches, roots, and leaf elongation. Ethephon is the main product of this class. After being imbibed by leaves it is hydrolyzed in the plant where it is 
converted into ethylene gas and translocated to other plant parts (Arteca, 1995; Taiz \& Zeiger, 2004). In addition to inhibiting canopy development, ethephon has also a considerable action in reducing flower stem emission.

\section{DEVELOPMENT INHIBITORS AND LAWN MANAGEMENT}

Recent research developments indicate that lawn management should combine mechanical cuttings with the application of plant growth inhibitors. This combination allows more adequate lawn management under several conditions of temperature and humidity. Thus, lawn management is understood as the capability of controlling different fluxes of plant growth viewing to improve, or at least not influencing, the visual quality of lawns (Watschke \& DiPaola, 1995).

The effects of synthetic compounds are similar to those observed in natural plant hormones, and these are dependent on plant species, dose, application time, number of applications, and environmental conditions at the time the product is applied. Therefore, plant growth inhibitors may have some undesirable effects when used without exacting criteria. Injury to lawns caused by growth regulators, which result in loss of visual quality, is frequently reported.

\section{Injury}

Leaf injury vary with environmental conditions in temperate climatic conditions; greenish to black necrosis is more likely to occur (Ervin \& Koski, 2001; Heckman et al., 2005; McCullough et al., 2006). Some research results have shown that such injury is due to a substantial increase in chlorophyll content in plant tissues, especially when some plant growth regulators of class A and B are used (Erwin \& Koski, 2001; Erwin et al., 2004; Sarvis III et al., 2009). Plants treated with inhibitors of gibberellin biosynthesis show higher levels of cytokinins (Figure 2) which stimulate

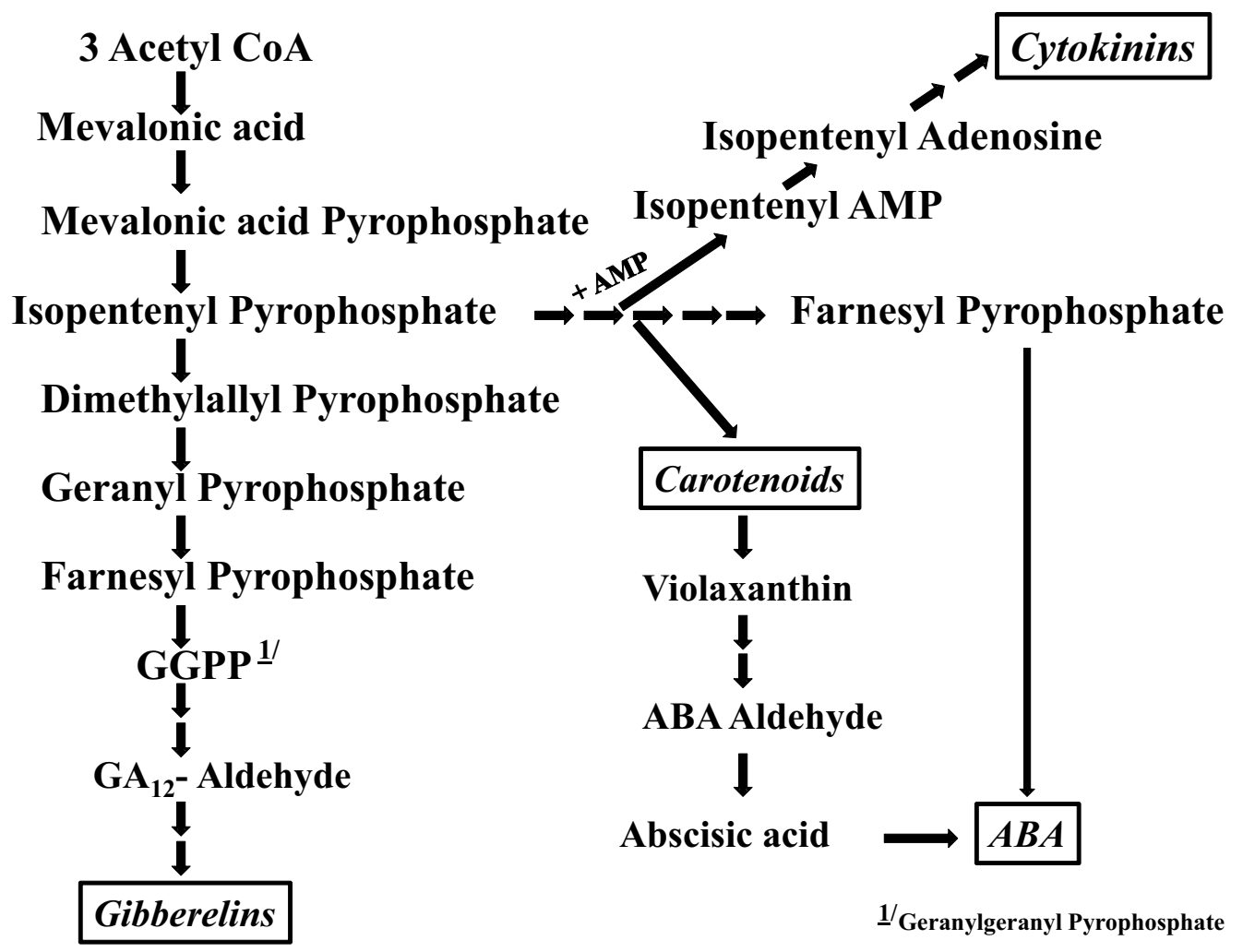

Figure 2 - Mevalonic acid via for the biosynthesis of gibberellins, cytokinins, and abscisic acid. 
chlorophyll biosynthesis (Binns, 1994; Arteca, 1995; Erwin \& Koski, 2001; Erwin et al., 2004; Veerasamy et al., 2007; Xing et al., 2009).

Under tropical conditions, injury is more characterized by leaf yellowing. This discoloration intensity varies from moderate to severe and, when too intense, may cause the drying of the leaf terminal part. Injury starts in a few days and may be found up to eight weeks after the product was applied. Thermal and water stresses may magnify such injury (Johnson, 1992a; Fagerness \& Yelverton, 2000; Heckman et al., 2001; McCullough et al., 2006; McCarty et al., 2011).

Discoloration and drying down of leaf tips are, apparently, associated with the disruption of the gibberellin biosynthesis process which, coupled with the temperature conditions prevailing in tropical regions, favors the release of ethylene in the plant (Taiz \& Zeiger, 2004).

There are several ways to solve the injury problem caused by development inhibitors. Using dying stuff is the simplest of them all and does not require exacting studies. The main dyes used are based on water-soluble acrylic latex. These compounds are totally selective for the several grass species that were initially developed to improve lawns color during the wintertime or to suppress lawns imperfections resulting from mechanical cuttings. Safe and quick results have intensified their use especially in lawns where television broadcasts sports activities. This technique, on the other hand, is inconvenient because it affects the color of shoes and clothes people wear when using lawns (Liu et al., 2007; Briscoe et al., 2010).

Some research work has shown that the deleterious effects that growth-inhibiting substances cause to plants may be quickly reverted with the use of supplemental sources of iron or nitrogen, which are important elements for the development of chlorophyll thus returning the green color to grass leaves (Johnson, 1997; Stier \& Rogers III, 2001; Zhang et al., 2002; Ervin et al., 2004; McDonald et al., 2006; Sarvis III, 2009). Undoubtedly, however, the best procedure to avoid plant injury is the fractioning of the dose or the sequential application of balanced doses of plant growth inhibitors. It is noteworthy that the application of single low doses usually results in low injury levels associated with short periods of plant height control or the emission of floral stems. High doses have the opposite effects, e.g., they reduce plant height for longer periods of time but with high levels of injury. This unbalance between efficiency and injury may be resolved by the sequential application of betteradjusted doses (Fagerness \& Yelverton, 2000; Lickfeldt et al, 2001; McCarty et al., 2004; Waltz Jr \& Whitwell, 2005; Ervin \& Zhang, 2007; McCullough et al., 2007).

\section{Plant development}

As previously mentioned, the effect of development inhibitors is directly associated with plant species, dose, application time, number of applications, and the prevailing environmental conditions during the application.

Most of the papers published up to the beginning of the 21 rst century presented results referring to sole doses of the most diverse growth inhibitors on the main grass species. In general, the results indicated growth reductions lasting 2 to 4 weeks after product application, but the production of chips was practically the same as those areas that had not been treated with the growth inhibitors (Johnson, 1992a,b; Johnson, 1997; Wiecko, 1997).

The first results of the sequential application of growth inhibitors were published by Fagerness \& Yelverton (2000), who reported that seasonally applied trinexapac-ethyl resulted in long growth reductions of Tifway Bermuda grass (Cynodon dactylon) and that clipping production during the whole experimental period was reduced to less than $40 \%$ of the total amount produced by the plants of the control treatment.

Regrowth in height is a common event for most of the tropical grasses. This is due to the fact that non-structural carbohydrates such as glucose, fructose, sucrose, and amides may be stored and used as energy reserve for stress tolerance, to recover dormancy and sprouting after the removal of the aerial parts (Murphy et al., 2001; Waltz Jr. \& Whitwell, 2005). 
The rapid recovery in height after plant cutting and single application of growth inhibitors is due, at first, to the non-structural carbohydrates redistribution which were stored in grass stolons and rhizomes soon after leaves had been cut for the application of growth regulators (McCarty et al., 2004; Waltz Jr. \& Whitwell, 2005; Ervin \& Zhang, 2007; McCullough et al., 2007). It is noteworthy that single doses of growth inhibitors of classes A and $B$ promote not only the reduction in gibberellins concentration, but also the increment of the total concentration of chlorophyll b in plant leaves up to two weeks after product application. As a result, the leaves become more efficient in capturing light energy and consequently there is an increment in $\mathrm{CO}_{2}$ fixation and production of new non-structural carbohydrates (Ervin \& Koshi, 2001; Ervin \& Zhang, 2007).

\section{Floral stem emission}

Visually, a lawn is impaired by an intense floral stem emission, mainly because the colors of floral stems are usually different from those of plant leaves. In addition to that, the floral stems may reach excessive heights, thus hindering the practice of sports. The most typical example is that of Bahia grass (Paspalum notatum, ) which is capable of emitting more than 100 inflorescences per square meter, and its floral can grow up to 80 cm of height (Yelverton et al., 1997).

The efficacy of plant growth inhibitors of classes A and B, such as flurprimidol, paclobutrazol, and trinexapac-ethyl, has been investigated but with still questionable results. Researchers agree that these products still lack efficiency as to inhibiting flowering. This is thought to be due to their capability of inhibiting in grass species, gibberellin biosynthesis but not cell division (Johnson, 1992a; Spak et al., 1993; Johnson, 1994).

So, the inhibitors of gibberellin biosynthesis act mainly on the cell elongation mechanism, allowing the floral primordial differentiation to occur. Total inhibition of inflorescence emission is only possible by Class C inhibitors (ethephon, amidochlor, mefluidide, and maleic hydrazide), which have a direct effect on the cell division mechanism and do not allow such a differentiation to occur (Davis \& Curry, 1991).

\section{THE MOST IMPORTANT GROWTH INHIBITOR COMPOUNDS}

\section{Trinexapac-ethyl}

Trinexapac-ethyl is a plant growth inhibitor belonging to the chemical group of the cyclohexanediones, among which are the herbicides inhibiting the ACCase enzyme, present in the metabolic route of lipids. Its chemical structure is similar to that of the graminicides sethoxydim and clethodim, although its action is directly associated with the inhibition of gibberellin biosynthesis (Adams et al., 1991; Fagerness \& Penner, 1998).

This growth inhibitor reduces the level of activity of gibberellins, mainly $\mathrm{GA}_{1}$, by reducing the activity of the $\mathrm{GA}_{20}-3 \beta$-hydroxilase enzyme. And the inhibition of the activity of that enzyme probably results from the competition between the growth regulator and 2-oxogluterate by the co-substratum $\mathrm{Fe}^{+2}$ / ascorbate-dependent dioxygenase (Adams et al., 1991). Trinexapac-ethyl, once foliarly absorbed, is translocated up to the growing points where it influences plant internodes elongation, eepecially (Tomlin, 1995).

Tan \& Qian (2003) observed that the application of $0.1 \mathrm{~kg}$ a.i. ha ${ }^{-1}$ of trinexapac-ethyl in Poa pratensis caused a reduction in $\mathrm{GA}_{1}$ concentration up to $47 \%$ and increased $\mathrm{GA}_{20}$ up to $146 \%$, thus confirming the hypothesis that trinexapac-ethyl inhibits $\mathrm{GA}_{1}$ biosynthesis by blocking the conversion of $\mathrm{GA}_{20}$ to $\mathrm{GA}_{1}$.

Research studies with trinexapac-ethyl showed that the growth inhibitor, when used at the dose of $0.2 \mathrm{~kg}$ a.i. ha ${ }^{-1}$, suppressed the growth of bermudagrass (Cynodon dactylon) plants up to 3 weeks after the application. Two applications of trinexapac-ethyl, the first one of $0.2 \mathrm{~kg}$ a.i. ha ${ }^{-1}$, and another one, 15 days later, of $0.1 \mathrm{~kg}$ a.i. ha $\mathrm{g}^{-1}$ increased the period of suppressed growth to five weeks. When the second application $\left(0.1 \mathrm{~kg} \mathrm{ha}^{-1}\right)$ was made, the period of suppressed growth fell back to 4 weeks (Johnson, 1992b). In another study, Johnson (1994) verified in C. dactylon plants that three applications of trinexapac-ethyl, the 
first of $0.2 \mathrm{~kg}$ a.i. ha ${ }^{-1}$ at the end of spring time and two successive doses of $0.1 \mathrm{~kg}$ a.i. $\mathrm{ha}^{-1} 4$ and 8 weeks after the first one, resulted in a growth suppression period of 12 weeks. They also observed that such period represented a reduction of $70 \%$ in the mechanical cuttings of the plants. Although plant density was not modified, the visual quality of the lawn was significantly affected by the three sequential applications of trinexapac-ethyl when compared to three applications of flurprimidol.

Ferrell et al. (2003), evaluating the sequential application of trinexapac-ethyl in Paspalum vaginatum, verified that the doses of 0.09 and $0.38 \mathrm{~kg}$ a.i. $\mathrm{ha}^{-1}$ caused reductions of 56 and $96 \%$, respectively, in the vegetative growth of the plants in a period of 10 weeks after the application. On the other hand, the highest dose caused $28 \%$ of injury to the grass while the lowest dose affected only $6 \%$ of the plants. Although damage to the visual quality of the lawns is likely to occur, the authors highlighted the importance of using plant growth inhibitors in order to reduce the number of mechanical cuttings.

As to the emission of floral stems, trinexapac-ethyl at the dose of $0.287 \mathrm{~kg}$ a.i. ha ${ }^{-1}$ in Poa pratensis plants and of $0.382 \mathrm{~kg}$ a.i. ha ${ }^{-1}$ in Lolium perene caused reductions of 43 and $57 \%$, respectively although the effects waned considerably four weeks after application (Fagerness \& Penner, 1998; Beasley et al., 2005). McCullough et al. (2007) observed reductions close to $80 \%$ in floral stem emission in plants of Dwarf Bermudagrass (Cynodon dactylon x C. transvaalensis BurttDavy) by submitting them to three sequential applications of trinexapac-ethyl at 7 day intervals.

Trinexapac-ethyl showed good results in $P$. notatum by significantly reducing plant growth and floral stem emission for a period of up to 8 weeks after the application (Johnson, 1990).

Among the few research results published in Brazil, those of Freitas et al. (2002) with P. notatum and of Maciel et al. (2011) with C. dactylon are to be highlighted since they showed the direct relation between increasing doses of trinexapac-ethyl and reduction in vegetative and reproductive growth of the plants, without discoloration of plant leaves. Choosing the doses to be used is dependent on the period during which mechanical cutting of the plants is to be avoided. So, it was possible to avoid plant cutting in $P$. notatum for up to 12 weeks with the application of $0.75 \mathrm{~kg}$ a.i. ha ${ }^{-1}$.

\section{Paclobutrazol}

Paclobutrazol is a compound of the triazole group, a very active group in plant growth control. Their capacity to reduce plant growth is due to their inhibiting of the kauren microsomal oxidation, which is catalyzed by the kaurene cytochrome oxidase P-450, the direct consequence of which is the inhibition of gibberellins synthesis. Paclobutrazol also acts on the inhibition of sterol biosynthesis; it reduces the amount of abscisic acid, ethylene, and indole-3-acetic acid, while augmenting the amount of cytokinins (Arteca, 1995). It may be absorbed by leaves, stems, and roots being translocated by the xylem up to the sub apical growth meristem where it will inhibit the synthesis of gibberellins and, consequently, cell elongation. Thus, the treated grass plants will continue to emit leaves, tillers, and inflorescences although all of them considerably shorter than those of the non-treated plants.

A considerable number of research work has been published concerning the use of paclobutrazol for the control of lawn plants. The results, nonetheless, are conflicting as to time of application, number of applications during the growth phase, doses, and, specially, grass species. A dose of $1.1 \mathrm{~kg}$ a.i. ha ${ }^{-1}$ of Paclobutrazol at the end of spring time suppressed growth of $C$. dactylon plants for three weeks. This suppression period was augmented of 1 week when the compound was reapplied at the dose of $0.56 \mathrm{~kg}$ a.i. ha-1, 15 days later (Johnson, 1989).

When the doses are planned to be apportioned, for applications made at the end of the spring and beginning of summer, the doses are necessarily larger than those used in other periods of the year because of the intense vegetative growth the plants are then undergoing, although high doses are the more likely to cause plant injury. For paclobutrazol 
applied during autumn, even when at high doses, the results are not as satisfactory. Moreover, the results do not last as much in comparison with applications made previously (Johnson, 1992a, 1994).

McCullough et al. (2004) reported to have had a reduction of $86 \%$ in the amount of clipping from the mechanical cutting of TifEagle Bermuda grass (C. dactylon $\mathrm{x}$ C. transvaalensis) plants when they were previously treated with two applications of $0.42 \mathrm{~g}$ a.i. $\mathrm{ha}^{-1}$ of paclobutrazol at three-week intervals. However, according to the authors, that procedure was considered to be unacceptable because of the level of injury it caused to the plants.

It is known that paclobutrazol has almost no effect on the inhibition of $P$. notatum plants development, mainly on the emission of floral stems (Johnson, 1990; Ferrel et al., 2003).

\section{Prohexadione-calcium}

Prohexadione-calcium, such as trinexapac-ethyl, acts by inhibiting gibberellin biosynthesis; they block the $3 \beta$-hydroxilation of $\mathrm{GA}_{20}$ to $\mathrm{GA}_{1}$. It has a considerable degree of vegetative growth suppression in plant species such as apple tree, tomato, rice, wheat, peanuts and wild radish (Nakayama et al., 1992). Its molecular structure is very similar to that of trinexapac-ethyl, this is the reason why both compounds have very similar effects (Rademacher, 2000). However, this similarity has not caught the attention of researchers as to its use in lawns. It is known that sequential applications of prohexadionecalcium at doses between 0.14 and $0.67 \mathrm{~kg}$ a.i. ha ${ }^{-1}$ at 3 week intervals result in significant reductions in dry matter production of Bermuda grass (C. dactylon), Kentucky blue grass (Poa pratensis), perennial rye grass (Lolium perenne), and Zoysia grass (Zoysia japonica). These reductions are equivalent to those caused by trinexapac-ethyl at doses of $0.7,0.22,0.60$, and $0.27 \mathrm{~kg}$ a.i. ha ${ }^{-1}$, respectively (Ervin \& Ok, 2001; Beam \& Askew, 2007).

\section{Flurprimidol}

Flurprimidol is a bioisosteric pyrimidine analogous to triazole (Lerouxet et al., 2005) with an action similar to that of inhibitors of sterol synthesis (Totten et al., 2006). It is a typical Class B plant growth inhibitor that acts at the beginning of the gibberellin synthesis by blocking the action of cytochrome P-450 monooxygenase gibberellin precursor. It is predominantly absorbed by the roots and persists for a considerably long period of time in the soil, which permits its action in the soil for long periods (Totten et al., 2006). The main effect of this inhibition is internode shortening and the consequent plant size reduction. It is preferably used when it is necessary to associate vegetative growth reduction with the control of leaf diseases in grasses because of its considerable fungicide action (Bigelow et al., 2007; Bigelow, 2012).

\section{Ethephon}

Ethephon is the active ingredient of some plant growth regulators; it is transformed into ethylene gas when exposed to $\mathrm{pH} 4.0$ or when added to water. It can penetrate the plant tissue, and move within the plant internal tissues. After a few hours, it is decomposed into ethylene, phosphate, and chloride (Gelernter \& Stowell, 2001). It reduces plant growth by inhibiting cell division (Taiz \& Zeiger, 2004). Its action is considered to be fast it starts immediately after its application, and it may be active for periods of three to four weeks, depending on the dose used.

Ethephon shows some peculiar properties, for example, it may modify the plant growth habit, gradually increase leaf density by the continual production of new small leaves, and possibly reduce the senescence process of old leaves. On the other hand, density of new branches is kept unaltered since the elongation of internodes is relatively decreased (Diesburg, 2000).

Although it was the most used compound before the development of gibberellin biosynthesis inhibitors, ethephon applied alone had the undesirable characteristics of causing clipping reductions of the order of only 10 to $41 \%$, plant injury, reductions in plant recuperation potential and reduction in lawn density (Stier et al., 2000; McCullough et al., 2004, 2005b). Together, all those factors favored the development of weed species and reduced 
the competitive potential of grass species. They also made it unfeasible to use two or more applications during the same growing season.

As previously mentioned, the potential use of ethephon was reevaluated during the 1990s because of its peculiar property of effectively promoting the inhibition of floral stem emission in lawns (McCullough et al., 2005b). Ethephon promotes modifications in the hormonal balance in favor of ethylene and, specially, an unbalance between this hormone and the cytokinins. This causes a reduction in the amount of energy required for cell division in the development and emission of floral stems (Eggens et al., 1989; Gelernter \& Stowell, 2001; McCullough et al., 2005b). On the other hand, ethephon has little to no effect on floral stems already emitted by the plant (Stier et al., 2000; Diesburg, 2000; McCullough et al., 2005b).

Nowadays, it is known that the application of ethephon in association with an inhibitor of Class A or B reduces injury levels and allows a synergic suppression of plant growth and floral stem emission (Kane \& Miller, 2003).

The association of ethephon at doses between 3.8 and $4.9 \mathrm{~kg}$ a.i. ha ${ }^{-1}$ and trinexapac-ethyl at doses between 50.0 and $140.0 \mathrm{~g}$ a.i. ha ${ }^{-1}$ or with flurprimidol at doses between 280.0 and $420.0 \mathrm{~g}$ a.i. ha $^{-1}$ allow the best results for growth reduction and floral stem emission of several grass species (Stier et al., 2000; Diesburg, 2000; McCullough et al., 2004, 2005c, d).

\section{Mefluidide}

Mefluidide was introduced in the United States in 1978 as a product capable of reducing lawns growth and flowering. Similarly to ethephon, mefluidide is a cell division inhibitor and it is used to reduce the production of floral stems. It may be absorbed by the leaves and it shows small translocation capacity to neighboring organs such as roots and lateral buds. Its absorption is faster at the petiole and the leaf base, regions where cell division and elongation occur; as a consequence, it causes a reduction of the leaf blade and plant height. Particularly, melfluidide promotes the disorderly growth of cells at the plant apexes, distorting the plant so as to hamper flower development (Field \& Witford, 1982).

Under optimal conditions, multiple applications of mefluidide can reduce floral stem production by $90 \%$ in the most important species of grass. In a way similar to that of ethephon, mefluidide does not act on floral stems already emitted. It is recommended that the application should be made approximately 14 days before the first floral stem emission flux during the lawn growing season (Gelernter $\&$ Stowell, 2001). However, as a result of the difficulty in predicting when plants will undergo the first floral stem emission flux and also because of the high level of injury caused to the plants by the multiple application of the product the use of mefluidide is restricted to low to medium technology level lawns.

Significant reductions in plant growth and floral stem emission resulted when mefluidide was applied alone at doses between 137.0 and $420.0 \mathrm{~g}$ a.i. ha ${ }^{-1}$ in several grass species (Green et al., 1990; Johnson, 1993; Heckman et al., 2005).

\section{IMPORTANT GROWTH INHIBITOR HERBICIDES}

\section{Glyphosate}

Glyphosate is a non-selective herbicide of systemic action belonging to the group of chemical derivates from glycine. It is foliarly absorbed with fast translocation in the plant tissues. Its action lies in the activity of the enzyme responsible for forming the amino acids tryptophan, tyrosine, and phenylalanine and other endogenous compounds. It also inhibits photosynthesis, the synthesis of nucleic acids, and stimulates ethylene production (Rodrigues, 1998). The specific locus of action of glyphosate is an enzyme in the shikimic acid via formally known as 5enolpyruvyl shikimate 3-phosphate synthase (EPSP synthase). The drastic inhibition of this enzyme causes a reduction in the levels of the aromatic amino acids and a slow paralysis of plant growth up to its death. Applied at low doses, glyphosate enables a balanced reduction of EPSP synthase up to the level in which it can stop plant growth without causing its death, thus acting as a growth inhibitor 
(Arteca, 1995). A research work carried out in the USA showed that the isopropylamine glyphosate salt applied at the dose of $0.2 \mathrm{~kg}$ a.i. ha ${ }^{-1}$ at the end of the spring reduced the growth of $P$. notatum plants for up to three weeks with no plant injury. When applied in association with 2,4-D at doses of $0.2+$ $0.3 \mathrm{~kg}$ a.i. ha ${ }^{-1}$ and $0.3+0.4 \mathrm{~kg}$ a.i. ha ${ }^{-1}$, glyphosate resulted in severe injury to the plants up to six weeks, although it reduced plant growth and floral stem emission for up to 10 weeks after the application (Johnson, 1990).

\section{Imazaquin, imazapic, and imazethapyr}

These three herbicides, which belong to the imidazolinones herbicide family, show a selective action, and they are also amino acids inhibitors. They both act on the inhibition of the acetyl hydroxide acid synthase (AHAS) synthesis or acetolactate synthase (ALS), an enzyme common to the biosynthesis of the three aliphatic branched chain amino acids: valine, leucine, and isoleucine. This inhibition interrupts protein synthesis, which interferes in DNA synthesis and cell growth (Rodrigues, 1998).

The herbicides are easily absorbed by roots and leaves and are also quickly translocated to plant tissues through the xylem and phloem to growing points where they accumulate (Arteca, 1995). Selectivity is achieved by the detoxifying capacity shown by some plant species (Tomlin, 1995).

Injury to Saint Augustine grass was reported by McCarty et al. (2004) when they used a single application of imazipac at $28 \mathrm{~g}$ a.i. ha ${ }^{-1}$ and a sequential application of 14 $+14 \mathrm{~g}$ a.i. ha ${ }^{-1}$ (with a 30 day interval); plant leaves had a shriveled appearance 14 days after the application, although that symptom had disappeared totally when the evaluation was made 28 days after the application. According to the authors, the single application of imazipac at $28 \mathrm{~g}$ a.i. ha ${ }^{-1}$ was more selective for Saint Augustine grass, resulting in a superior visual quality than that of the sequential application of $14+14 \mathrm{~g}$ a.i. $\mathrm{ha}^{-1}$. McCarty et al. (2004) also reported to have observed that the production of clippings from Saint Augustinegrass plants submitted to the single dose application of $28 \mathrm{~g}$ a.i. ha ${ }^{-1}$ was $45 \%$ less than that observed for the control treatment although that difference was found to be statistically non significant. When applied as a sole single or double application of $14 \mathrm{~g}$ a.i. ha ${ }^{-1}$, imazipac caused a $35 \%$ reduction in floral stem emission up to 49 days after the application when compared with the control treatment results. Although floral stem emission was reduced by the treatments, the authors verified that it was below the level of $70 \%$, which was proposed by Johnson (1994) as ideal.

The application of $0.08 \mathrm{~kg}$ a.i. ha ${ }^{-1}$ of imazethapyr at the end of spring, inhibited vegetative growth of $P$. notatum plants up to five weeks after the application, and the emission of floral stems for up to 10 weeks. However, 25 to $30 \%$ of plant injury occurred (Johnson, 1990). Goatley et al. (1996) reported that imazaquin at the dose of $0.42 \mathrm{~g}$ a.i. ha ${ }^{-1}$ applied at three different moments of the plant cycle (at the end of spring, at the beginning of summer, and at the end of summer) caused low levels of injury to the plants and reductions of up to $80 \%$ in floral stem emission up to eight weeks after the application, regardless of the time the product was applied, but the product was not efficient in reducing plant growth; six weeks after the application, the plants were as tall as those of the control treatment.

Very interesting results were reported by Baker et al. (1999), who used a single application of imazipac or imazipac combined with imazaquin and verified reductions of 85 and $100 \%$, respectively, in the production of floral stems by Bahiagrass plants during a period of 12 weeks. The sequential application of the same products at the same doses eight weeks after the first treatment resulted in a reduction of $100 \%$ in floral stem production and prolonged the effect to sixteen weeks after the application.

\section{Metsulfuron-methyl}

Metsulfuron-methyl is a herbicide belonging to the sulfonylureas herbicide family which acts by inhibiting amino acids synthesis. Similarly to imidazolinones, metsulfuron-methyl is an irreversible inhibitor of acetolactate synthase, thus 
blocking the synthesis of the essential amino acids valine, leucine, and isoleucine (Vidal, 1997).

After it is absorbed by the leaves, it is rapidly translocated to the internal tissues of the plant through xylem and phloem and becomes accumulated at the apical bud and growing points of roots where it inhibits cell division by paralyzing plant growth in plants susceptible to the product (Tomlin, 1995). Preliminary studies carried out by Miller \& King (1983) showed that metsulfuron-methyl was promising to control the growth of C. dactylon plants. Rogers et al. (1987) verified that metsulfuron-methyl caused no injury to C. dactylon plants even when applied at high doses such as $140 \mathrm{~g}$ a.i. ha ${ }^{-1}$, but the product was not capable of causing great reductions in plant growth, mainly when applied at the end of summer.

\section{Bispyribac-sodium}

Bispyribac-sodium is a herbicide capable of inhibiting acetolactate synthase belonging to the pyrimdinyloxy benzoic acids herbicide family It acts by blocking the branch of the biochemical chain which produces the amino acids leucine, isoleucine, and valine in susceptible plants. It was initially used to control weed plants in high technology sports lawns (Lycan \& Hart, 2005). However, it was soon realized that the bispyribac-sodium applications used to control weed plants caused unacceptable levels of lawn chlorosis (Fagerness \& Penner, 1998; McDonald et al., 2006).

The few papers found in the literature report that bispyribac-sodium, applied in single or sequential applications of 40 to $60 \mathrm{~g}$ a.i. ha ${ }^{-1}$, suppresses the development of Festuca arundinaceae, Festuca rubra, P. pratensis, L. perene, and Agrostis palustres plants under greenhouse conditions (Fagerness \& Penner, 1998). Lycan \& Hart (2005) used single applications ranging from 39 to $296 \mathrm{~g}$ a.i. ha ${ }^{-1}$ to plants of Kentucky blue grass ( $P$. pratensis) and observed that the levels of injury were always lower than $28 \%$. In addition, they also reported increasing levels of injury with increasing doses of the product, and for doses of 74 and $296 \mathrm{~g}$ a.i. ha ${ }^{-1}$, there were reductions of 19 and $35 \%$ of chips resulting from mechanical cutting of the lawn.

As previously mentioned for other compounds, the deleterious effects caused by bispyribac-sodium may be effectively masked when it is used in combination with iron chelates and nitrogen (McDonald et al., 2006).

This literature review shows that the use of plant growth regulators in lawns is still in need of much research, mainly on the effects of those products in each one of the species used for that purpose under Brazilian conditions. Doses, application time, and the combination of products for plant growth control and floral stem development are subjects to be investigated because there is no official recommendation for the management of lawns by means of plant growth regulators in Brazil.

\section{LITERATURE CITED}

ADAMS, R. et al. Studies on the action of the new growth retardant CGA 163935. In: BRITISH CROP PROTECTION CONFERENCE, 1991. p. 1133-1138.

ARTECA, R. N. Plant growth substances: principles and applications. New York: Champman \& Hall, 1995. 332 p.

BAKER, R. D. et al. Bahiagrass (Paspalum notatum) seedhead suppression following consecutive early applications of plant growth retardants. Weed Technol., v. 13, n. 2 , p. $378-384,1999$

BEAM, J. B.; ASKEW, S. D. Fate of prohexadione calcium in annual bluegrass (Poa Annua) and three turfgrasses.

Weed Sci., v. 55, n. 6, p. 541-545, 2007.

BEASLEY, J. S.; BRANHAM, B. E.; ORTIZ-RIBBING, L. M. Trinexapac-ethyl affects Kentucky bluegrass root architecture. HortScience, v. 40, n. 5, p. 1539-1542, 2005.

BIGELOW, C. A.; BUNNELL, B. T.; HARDEBECK, G. A. Monthly flurprimidol applications reduce annual bluegrass populations in a creeping bentgrass fairway. Applied Turfgrass Science, doi:10.1094/ATS-2007-0508-02-RS 2007. Available in: $<\mathrm{http}: / /$

www.plantmanagementnetwork.org/pub/ats/research/2007/ flurprimidol/>. Access in: Dez 102012

BIGELOW, C. A. Plant growth regulators in bentgrass turf areas. USGA Green Section Record, v. 50, n. 8, p. 1-4, 2012 .

BINNS, A. N. Cytokinin accumulation and action: biochemical, genetic, and molecular approaches. Ann. Rev. Plant Physiol., v. 45, n. 1, p. 173-196, 1994. 
BRISCOE, K.; MILLER, G.; BRINTON, S. Evaluation of green turf colorants as an alternative to overseeding on putting greens. Appl. Turf. Sci., v. 35, n. 3, p. 1-8, 2010.

BURPEE, L. L.; GREEN, D. L.; STEPHENS, S. L. Interactive effects of plant growth regulators and fungicides on epidemics of dollar spot in creeping Bentgrass. Plant Dis. v. 80, n. 11, p. $1245-1250,1996$

BURPEE, L. L. Effects of plant growth regulators and fungicides in Rhizoctonia blight of Tall Fescue. Crop Protec., v. 17, n. 6 , p. $503-507,1998$

COOKE, A. R. The future of specialty plant growth regulators. Proc. Plant Growth Regul. Soc. Am., v. 14, p. 2-7, 1987

DANNEBERGER, T. K.; STREET, J. Turfgrass growth substances. Golf Course Mgmt., v. 59, n. 4, p. 80-88, 1990

DAVIS, T. D.; CURRY, E. A. Chemical regulation of vegetative growth. Crit. Rev. Plant Sci., v. 10, n. 2, p. 151-188, 1991.

DERNOEDEN, P. H. Four-year response of a Kentucky Bluegrass-Red Fescue turf to plant growth retardants. Agron. J., v. 76, n. 5, p. 807-813, 1984.

DIESBURG, K. Growth regulators boost density in different ways. Golf Course Mgmt., v. 68, n. 2, p. 61-62, 2000 .

EGGENS, J. L. et al. The effect of ethephon on annual bluegrass and creeping bentgrass growth. Can. J. Plant Sci., v. 69, n. 4 , p. $1553-1557,1989$.

ERVIN, E. H.; KOSKI, A. J. Trinexapac-ethyl increases Kentucky bluegrass leaf cell density and chlorophyll concentration. HortScience, v. 36, n. 4, p. 787-789, 2001

ERVIN, E. H. et al. Trinexapac-ethyl, propiconazole, iron and biostimulant effects on shaded creeping bentgrass

HortTechnol., v. 14, n. 4, p. 500-506, 2004

ERVIN, E. H.; OK, C. Influence of plant growth regulators on suppression and quality of 'Meyer' zoysiagrass. J. Environ. Hortic., v. 19, n. 2, p. 57-60, 2001.

ERVIN, E. H.; ZHANG, W. Influence of sequential trinexapac-ethyl applications on cytokinin content in creeping bentgrass, kentucky bluegrass, and hybrid bermudagrass Crop Sci., v. 47, n. 5, p. 2145-2151, 2007

FAGERNESS, M. J.; PENNER, D. Spray application parameters that influence the growth inhibiting effects of trinexapac-ethyl. Crop Sci., v. 38, n. 4, p. 1028-1035, 1998.
FAGERNESS, M. J.; YELVERTON, F. H. Tissue production and quality of 'tifway' bermudagrass as affected by seasonal application patterns of trinexapac-ethyl. Crop Sci., v. 40, n. 2 , p. 493-497, 2000.

FERRELL, J. A. et al. Seashore paspalum response to trinexapac-ethyl and paclobutrazol. Hortscience, v. 38, n. 4, p. 605-606, 2003.

FIELD, R. S.; WITFORD, A. R. Effect of simulated mowing on the translocation of mefluidide in perennial ryegrass (Lolium perenne L.). Weed Res., v. 22, n. 4, p. 177-181, 1982.

FREEBORG, R. P.; DANIEL, W. H. Growth regulation of Poa pratensis L. In: INTERNATIONAL TURF RESEARCH CONFERENCE OF UNIVERSITY OF GUELPH, 4., 1081

Proceedings... Guelph: University of Guelph, 1981. p. $477-486$

FREITAS, F. C. L. et al. Efeitos de trinexapac-ethyl sobre o crescimento e florescimento da grama-batatais.

Planta Daninha, v. 20, n. 3, p. 475-484, 2002.

GELERNTER, W.; STOWELL, L. J. Advances in Poa seedhead management. Golf Course Mgmt., v. 69, n. 10, p. $49-53,2001$

GOATLEY, J. M.; MADDOX, V. L.; WATKINS, R. M. Growth regulation of bahiagrass (Paspalum notatum Fluegge) with imazaquin and AC 263,222. HortScience, v. 31, n. 3, p. 396-399, 1996.

GREEN, R. L.; KIM, K. S.; BEARD, J. B. Effects of flurprimidol, mefluidide and soil moisture on St. Augustinegrass evapotranspiration rate. HortScience, v. 25, n. 4 , , p. $439-441,1990$

HECKMAN, N. L.; HORST, G. L.; GAUSSOIN, R. E. Influence of trinexapac-ethyl on specific leaf weight and chlorophyll content of Poa pratensis. Inter. Turfgrass Soc. Res. J., v. 9, n. 4, p. 287-290, 2001

HECKMAN, N. L. et al. Growth regulator effects on cellular characteristics of two turfgrass species. Inter. Turfgrass Soc. Res. J., v. 10, n. 8, p. 857-861, 2005.

HUANG, B. Plant growth regulators: What and why. Golf Course Mgmt., v. 75, n. 1, p. 157-160, 2007.

JIANG, H.; FRY, J. Drought responses of perennial Ryegrass treated with plant growth regulators. HortScience, v. 32, n. 2, p. $270-273.1998$.

JOHNSON, B. J. Response of tall fescues (Festuca arundinacea) to plant growth regulators and mowing frequency. Weed Technol., v. 3, n. 1, p. 54-59, 1989. 
JOHNSON, B. J. Influence of frequency and dates of plant growth regulator applications to centipedegrass on seedhead formation and turf quality. HortScience, v. 15, n. 3, p. 412-416, 1990.

JOHNSON, B. L. Response of Tifway bermudagrass to rate and frequency of flurprimidol and paclobutrazol application. HortScience, v. 27, n. 3, p. 230-233. 1992a

JOHNSON, B. L. Response of bermudagrass (Cynodon sp) to CGA 163935. Weed Technol., v. 6, n. 3, p. 577-582, $1992 b$.

JOHNSON, B. J. Response of Tall Fescue to Plant Growth Regulators and Mowing Frequencies. J. Environ. Hortic., v. 11, n. 4 , p. $163-167,1993$

JOHNSON, B. J. Influence of plant growth regulators and mowing on two Bermudagrasses. Agron. J., v. 86, n. 3 , p. 805-810. 1994.

JOHNSON, B. J. Growth of Tifway bermudagrass following application of nitrogen and iron with trinexapac-ethyl.

HortScience, v. 32, n. 1, p. 241-242, 1997.

KANE, R.; MILLER, L. Field testing plant growth regulators and wetting agents for annual bluegrass seedhead suppression USGA Green Section Record, v. 41, n. 7, p. 21-26, 2003

LEROUX, F.; JESCHKE, P.; SCHLOSSER, M. á-Fluorinated ethers, thioethers, and amines: Anomerically biased species.

Chem. Rev., v. 105, n. 3, p. 827-856, 2005.

LICKFELDT, D. W. et al. Implications of repeated trinexapac-ethyl applications on Kentucky bluegrass Agron. J., v. 93, n. 5, p. 1164-1168, 2001

LIU, H. et al. Painting dormant bermudagrass putting greens Golf Course Mgmt., v. 75, n. 11, p. 86-91, 2007.

LYCAN, D. W.; HART, S. E. Cool-season turfgrass response to bispyribac-sodium. HortScience, v. 40, n. 5 , p. $1552-1555,2005$

MACIEL, C. D. G. et al. Desenvolvimento de gramados submetidos à aplicação de retardadores de crescimento em diferentes condições de luminosidade. Planta Daninha, v. 29, n. 2, p. 383-395, 2011.

MARCUM, K. JANG, K. Effects of plant growth regulators on Tall Fescue rooting and water use. J. Turfgrass Manag., v. 2, n. 1, p. 13-27, 1997.

McCARTY, L. B. et al. St. Augustinegrass response to plant growth retardants. Crop Sci., v. 44, n. 4, p. 1323-1329, 2004

McCARTY, L. B. et al. 'Ttifeagle' bermudagrass response to plant growth regulators and mowing height. Agron. J., v. 103, n. 4, p. 988-994, 2011.
McCUlLOUGH, P. E. et al. Response of 'TifEagle' bermudagrass to seven plant growth regulators. HortScience, v. 39, n. 7, p. 1759-1762, 2004.

McCUllough, P. E.; LIU, H.; McCARTY, L. B. Dwarf bermudagrass responses to flurprimidol and paclobutrazol. HortScience, v. 40, n. 5, p. 1549-1551, 2005a.

McCUllOUGH, P. E.; LIU, H.; McCARTY, L. B. Ethephon and gibberellic acid inhibitors influence creeping bentgrass putting green quality and ball roll distances. HortScience, v. 40, n. 4, p. 1902-1903, 2005b.

McCULLOUGH, P. E.; LIU, H.; McCARTY, L. B. Mowing operations influence creeping bentgrass putting green ball roll following plant growth regulator applications. HortScience, v. 40 , n. 2 , p. $471-474,2005$ c.

McCUlloUgh, P. E.; LIU, H.; McCARTY, L. B. Response of creeping bentgrass to nitrogen and ethephon. HortScience, v. 40, n. 3 , p. $836-838,2005$ d.

McCULLOUGH, P. E. et al. Bermudagrass putting green growth, color, and nutrient partitioning influenced by nitrogen and trinexapac-ethyl. Crop Sci., v. 46, n. 4, p. 1515-1525, 2006.

McCULLOUGH, P. E. et al. Trinexapac-ethyl application regimens influence growth, quality, and performance of bermuda grass and creeping bentgrass putting greens.

Crop Sci., v. 47, n. 5, p. 2138-2144, 2007.

McDONALD, S. J.; DERNOEDEN, P. H.; KAMINSKI, J. E. Creeping bentgrass tolerance and annual bluegrass control with bispyribac-sodium tank-mixed with iron and nitrogen. Appl. Turfgrass Sci. doi: 10.1094/ATS-2006-0811-01-RS. 2006. Available in: http://www.turf.uconn.edu/pdf/research/ kaminski/ats_0811_01_rs.pdf. Access in: Nov. 102012.

MILLER, E. M.; KING, J. W. DPX6376 and DPX-5648 (Oust) on common bermudagrass (Cynodon dactylon) turf. Proc. Southern Weed Sci. Soc., v. 36, p. 122, 1983.

MITTLESTEADT, T. L. Low-impact conversion of coolseason turf to 'patriot' bermudagrass. Inter. Turfgrass Soc. Res. J., v. 11, n. 9, p. 1205-1212, 2009.

MURPHY, T. R. et al. Turfgrass plant growth regulators. In: Best golf course management practices. Upper Saddle River: Prentice Hall, 2001. p. 552-561.

NAKAYAMA, I. et al. Effects of a plant-growth regulator, prohexadione-calcium (BX 112), on the endogenous levels of gibberellins in rice. Jpn. Soc. Plant Physiol., v. 33, n. 1, p. $59-62,1992$

RADEMACHER, W. Growth retardants: effects on gibberellin biosynthesis and other metabolic pathways. Ann.

Rev. Plant Physiol., v. 51, n. 3, p. 501-531, 2000. 
RODRIGUES, B. N. Guia de herbicidas. Londrina: 1998. $646 \mathrm{p}$.

ROGERS, J. N.; MILLER, E. M.; KING, W. Growth retardation of bermudagrass with metsulfuron methyl and sulfometuron methyl. Agron. J., v. 79, n. 2, p. 225-229, 1987

SARVIS III, W. G. et al. Performance of Poa trivialis as overseeded turf under shade conditions. Inter. Turfgrass Soc. Res. J., v. 11, n. 2, p. 837-847, 2009

SPAK, D. R. et al. Tall fescue sward dynamics: II. Influence of four plant growth regulators. Crop Sci., v. 33, n. 2, p. $304-310,1993$

STIER, J.; REICHER, Z.; HARDEBECK, G. Effect of the growth regulator proxy on creeping bentgrass fairway turf. J. Environ. Hortic., v. 18, n. 1, p. 53-58, 2000.

STIER, J. A brief review of turfgrass growth regulators. The Grass Roots, v. 35, n. 3, p. 4-9, 2006

STIER, J.; ROGERS III, J. N. Trinexapac-ethyl and iron effects on supina and Kentucky bluegrasses under low irradiance. Crop Sci., v. 41, n. 2, p. 457-465, 2001.

TAN, Z. G.; QIAN, Y. L. Light intensity affects gibberellic acid content in Kentucky bluegrass. Hortscience, v. 38, n. 1, p. 113-116, 2003.

TAIZ, L.; ZEIGER, E. Fisiologia vegetal. 3.ed., Porto Alegre: Artmed, 2004. 719 p

TOMLIN, C. The pesticide manual handboock. London: British Crop Protection Council, 1995. 1341 p.

TOTTEN, F. W.; TOLE, J.E.; McCARTY, L. B. 'Tifway' bermudagrass growth regulation with the use of trinexapacethyl and flurprimidol. Weed Technol., v. 20, n. 3, p. 702-705, 2006.
VIDAL, R. A. Herbicidas: mecanismo de ação e resistência de plantas. Porto Alegre: 1997. 165 p.

VEERASAMY, M.; HE, Y; HUANG, H. Leaf Senescence and protein metabolism in creeping bentgrass exposed to heat stress and treated with cytokinins. J. Am. Soc. Hortic. Sci., v. 132 , n. 4 , p. $467-472,2007$.

XING, J. et al. Suppression of shade- or heat-induced leaf senescence in creeping bentgrass through transformation with the ipt gene for cytokinin synthesis. J. Am. Soc. Hort. Sci., n. 134, n. 6, p. 602-609, 2009.

YELVERTON, F. H.; McCARTY, L. B.; MURPHY, T. H. Effects of imazameth on the growth of Paspalum notatum fluegge. Inter. Turfgrass Soc. Res. J., v. 8, n. 8, p. 1085-1094, 1997.

WALTZ JR, F. C.; WHITWELL, T. Trinexapac-ethyl effects on total nonstructural carbohydrates of field grown hybrid bermudagrass. Int. Turfgrass Soc. Res. J., v. 10, n. 8, p. 899-903, 2005.

WATSCHKE, T. L.; WEHNER, D. J.; DUICH, J. M. Initial and residual effects of growth regulators on a PennstarFylking Kentucky Bluegrass blend. Proc. Northeast. Weed Sci. Soc., v. 34, p. 382-388, 1977.

WATSCHKE, T. L.; DIPAOLA, J. M. Plant growth regulators. Golf Course Mgmt., v. 63, n. 3, p. 59-62, 1995.

WIECKO, G. Response of 'Tifway' bermudagrass to trinexapac-ethyl. J. Turfgrass Manag., v. 2, n. 2, p. 29-36, 1997.

ZHANG, $\mathrm{X}$. et al. Creeping bentgrass physiological responses to natural plant growth regulators and iron under two regimes. HortScience, v. 37, n. 6, p. 898-902, 2002. 